\title{
The State of the Field: A Basic Bibliography on Astrological Cultic Practices in Japan.
}

\section{Lucia Dolce}

In spite of the importance of the stars in the religious life of Japan, scholarly works that look at the variety of the ritual practices related to astral bodies are few in Japanese, and hardly existent in Western languages, with the exception of a ground-breaking study on directional interdictions in French (Frank 1998).

The first attempt to explore astrological practices in a comprehensive way was published in the 1970s (Kanezaki 1974), a few years after a classic volume on Japanese astronomy appeared, first in English and then in Japanese (Nakayama 1969 and 1972). The study by Kanezaki brings together historical data and popular practices, and is to date the best available outline of the different forms that the worship took. A single volume on the stars has been published since (Sano 1994), which however includes essays previously published in academic journals and local histories on two stellar deities. These studies mostly refer to China as the source of the knowledge on stars, but scholars of Indian astronomy have also pointed out the significance of the connections between Japanese and Indo-European astrology (Yano 1986, 2004).

Dedicated studies on astral deities have concentrated on two bodhisattvas, Kōkuzō and Myōken/Pole Star, which have been objects of ethnographic analysis (Sanō 1991 and 1996) and art historical interest (Izumi, Hayashi On). The specific iconography of star mandalas is also outlined by Takeda (1995), and discussed in several studies by Tsuda Tetsuei, of which a summary is given in his essay included in the present volume. An excellent compendium of the Tantric liturgies for the stars is the two-volume study by Morita (1944).

Yin-yang practices, on the other hand, have been the concern of a large scholarship that ranges from the classic volumes by Murayama Shüichi

Lucia Dolce, 'The State of the Field: A Basic Bibliography on Astrological Cultic Practices in Japan', Culture And Cosmos, Vol. 10 no 1 and 2, Spring/Summer and Autumn Winter 2006, pp. 45-48. www.CultureAndCosmos.com 
46 The Worship of Celestial Bodies in Japan

(1981 and 1987) to the recent analysis of the political context of Onmyōdō practitioners (Hayashi and Koike), and have seen an upsurge of interest in the last decade. The boom in Abe no seimei's popularity, which has produced several works of popular culture, such as the extraordinarily successful manga series designed by Okano Reiko (Yumemakura and Okano 1994-2001), has also attracted a great deal of attention from literature specialists, historians and anthropologists (Saitō 2004, Shigeta 2005).

The shelves of Japanese bookshops are also filled with books authored by contemporary practising astrologers, who at times offer modern interpretations of traditional texts and imagery (Uesumi 1999).

The bibliography that follows lists monographs and edited volumes in alphabetic order, and does not include journal articles.

Frank, Bernard, Kata-imi et kata-tagae: Étude sur les interdits de direction à l’Époque Heian, Paris: Collége de France, 1998. (Rev. ed.; $1958^{1 \text { st }}$. Jap. ed. Tokyo: 1989.)

Hayashi Makoto 林淳 and Koike Junichi 小池淳一 ed., Onmyōdō no $k \overline{o g} i$ 陰陽道の講義 [Lectures on Onmyōdō], Kyoto: Sagano shoin, 2002.

Hayashi On 林温, Myōken bosatsu to hoshi mandara 妙見菩薩と星曼茶羅 [The Bodhisattva Myōken and the Star Mandalas], Nihon no bijutsu, vol. 377 (1997).

Itō Kazuo 伊藤一男, Myōken shinkō to Chibashi 妙見信仰と千葉氏 [The Worship of Myōken and the Chiba clan], Nagareyama: Ronshobō, 1980 .

Izumi Takeo 泉武夫執, Kokūzō bosatsu zō 虚空蔵菩薩像 [Icons of the Bodhisattva Kokūzō], Nihon no bijutsu, vol. 380 (1998).

Kanagawa kenritsu Kanazawa bunko 神奈川県立金沢文庫, Chüsei no uranai 中世の占い [Medieval Divination], special exhibition, Kanazaka bunko: 1989.

Culture and Cosmos 
Kanezashi Shōzō 金指正三, Hoshi uranai, hoshi matsuri 星占い星祭り [Predicting through the stars, venerating the stars], Tokyo: Seiabō, 1974.

Koyomi no kai 暦の会 ed., Koyomi no hyakka jiten 暦の百科事典 [Encyclopaedia of Calendars], Tokyo: 1986.

Morita Ryūsen 森田龍僊, Mikkyō senseihō 密教占星法 [Astrological Rituals in Tantric Buddhism], 2 vols., Kyoto: Rinsen shoten, 1944.

Murayama Shūichi 村山修一, Nihon onmyōdō shisōsetsu 日本陰陽道史総説 [Historical Interpretations of Yin-yang Thought in Japan], Tokyo: Hanawa shobō, 1981.

Murayama Shūichi, Nihon onmyōdō shiwa 日本陰陽道史話 [A Historical Account of Yin-yang Thought in Japan], Osaka: Osaka shoseki, 1987.

Murayama Shūichi et al., eds., Onmyōdō sōsho 陰陽道叢書 [Collected Sources of Onmyōdō], 4 vols., Tokyo: Meichō shuppan, 1991-93.

Nakayama, Shigeru, A History of Japanese Astronomy: Chinese Background and Western Impact. Cambridge: Harvard University Press, 1969. (Jap. edition: Nihon no tenmongaku 日本の天文学, Tokyo: Iwanami, 1972).

Okada Yoshirō 岡田 芳朗 and Akune Suetada 阿久根 未忠, eds., Gendai koyomi yomitoki jiten 現代こよみ読夕解き事典 [A Contemporary Dictionary for Interpreting Calendars] Tokyo: Kashiwaōshobō, 1993.

Yumemakura Baku 夢枕獏 and Okano Reiko 岡野玲子, Onmyōji 陰陽師 [The Yin-yang Specialist], 11 vols., Tokyo: Hakusensha, 19922001 .

Saitō Hideki 佐藤英喜, Abe no seimei -inyō no tassha nari 安倍晴一陰陽の達者なり [Abe no Seimei: Proficient in Yin-yang], Kyoto: Mineruba shobō, 2004. 
48 The Worship of Celestial Bodies in Japan

Sano Kenji 佐野賢治, Kokūzō shinkō 虚空蔵信仰 [The Cult of Kokūzō], Tokyo: Yūzankaku, 1991.

Sano Kenji, Kokūzō bosatsu shinkō no kenkyū. Nihonteki bukkyō juyō to bukkyō minzokugaku 虚空蔵菩薩信仰の研究

一日本的仏教受容と仏教民俗学 [Studies on the Cult of the Bodhisattva Kokūzō: The Japanese reception of Buddhism and Buddhist folklore studies], Tokyo: Yoshikawa kōbunkan, 1996.

Sano Kenji, ed. Hoshi no shinkō: Myōken, Kokūzō 星の信仰: 妙見 - 虚空蔵 [The Worship of Stars: Myōken and Kokūzō], Tokyo: Hokushindō, 1994.

Shigeta Shinichi 繁田信一著, Heian kizoku to onmyōji: Abe no Seimei no rekishi minzokugaku 平安貴族と陰陽師 - 安倍晴明の歴史民俗学 [The Aristocracy of the Heian Period and the Yin-yang Specialists: A Historical Ethnography of Abe no Seimei], Tokyo: Yoshikawa kōbunkan, 2005.

Takeda Kazuaki 武田和昭, Hoshi mandara no kenkyu 星曼茶羅の研究 [Studies on Star Mandalas], Kyoto: Hōzōkan, 1995.

Uesumi Setsuko 上住節子，Sukuyō senbō 宿曜占法 [Astrological Methods of Divination], 2 vols., Tokyo: Daizō shuppan, 1999.

Yano Michio 矢野道雄, Hoshi uranai no bunka kōryūshi 星占いの文化交流史 [History of Cultural Exchanges in Astrology], Tokyo: Keisōshōbo, 2004.

Yano Michio, Mikkyō senseijutsu. Sukuyōdō to Indo senseijutsu 密教占星術一宿曜道とインド占星術 [Tantric Astrology: Sukuyōdō and Indian Astrology], Tokyo: Tōkyō bijutsu, 1986.

Culture and Cosmos 